Chirurgia (2018) 113: 516-523

No. 4, July - August

Copyright@ Celsius

http://dx.doi.org/10.21614/chirurgia.113.4.516

\title{
The Impact of Intraoperative Fluid Therapy and Body Temperature on Surgical Site Infection - Re-Assessment of a Randomized Trial
}

\author{
Sofie Kirchhoff Gundersen ${ }^{1}$, Christian Sylvest Meyhoff ${ }^{2}$, Jørn Wetterslev ${ }^{3}$, Lars Simon Rasmussen ${ }^{4}$, \\ Lars Nannestad Jørgensen ${ }^{1}$ on behalf of the PROXI Trial Group
}

\author{
'Digestive Disease Center, Bispebjerg Hospital, University of Copenhagen, Copenhagen, Denmark \\ ${ }^{2}$ Department of Anaesthesiology, Bispebjerg Hospital, University of Copenhagen, Copenhagen, Denmark \\ ${ }^{3}$ Copenhagen Trial Unit, Centre for Clinical Intervention Research, Rigshospitalet, Copenhagen \\ University of Copenhagen, Copenhagen, Denmark \\ ${ }^{4}$ Department of Anaesthesia, Centre of Head and Orthopaedics, Rigshospitalet, University of Copenhagen, Copenhagen, Denmark
}

Corresponding author:

Sofie Kirchhoff Gundersen MD Lyngevej 201, DK-3450Allerød Denmark

E-mail: sofisken@gmail.com

\section{Rezumat}

Impactul terapiei lichidiene intraoperatorii și a temperaturii corporale asupra infecției plăgii chirurgicale - reevaluare a unui studiu clinic randomizat

Contextul: Utilizarea oxigenului suplimentar în timpul intervenției chirurgicale pentru a reduce incidența infecțiilor plăgii chirurgicale (IPC) a fost studiată în cadrul studiului clinic PROXI, care nu a descoperit o frecvență redusă a infecțiilor. Ulterior, s-a sugerat că terapia lichidiană restrictivă şi hipotermia în cazul unor pacienți ar putea explica lipsa efectelor benefice a administrării oxigenului suplimentar. Am evaluat asocierea incidenței IPC şi doi factori perioperatori, volumul fluidului administrat şi temperatura corporală.

Metode: Am folosit informații din studiul clinic PROXI, care a inclus 1.386 de pacienți supuşi laparotomiei, cărora li s-a administrat randomizat $80 \%$ sau $30 \%$ oxigen în timpul interventiei chirurgicale. S-a calculat un index al lichidelor administrate pentru fiecare pacient: volumul lichidelor administrate/ greutate corporală / durata operației.

Rezultate: Au suferit de IPC: $18,9 \%$ din pacientii cu un indice scăzut (RR (risc relativ) $=0.86 ; \mathrm{P}=0.41), 20.4 \%$ din pacienții cu indice crescut $(\mathrm{RR}=1.49 ; \mathrm{P}=0.05), 19,7 \%$ din pacientii cu hipotermie $(\mathrm{RR}=1.28 ; \mathrm{P}=0.25)$ şi $25,0 \%$ din pacienții cu hipertermie 
$(\mathrm{RR}=1.26 ; \mathrm{P}=0.52)$. Un risc crescut de IPC $(\mathrm{RR}=3.15 ; \mathrm{P}=0.01)$ a fost identificat la pacienții care au suferit de hipotermie şi intervenție chirurgicală de urgență.

Concluzii: S-a observat un trend crescător al apariției IPC la pacienții care au primit o cantitate mai mare de lichid intravenos. Nu s-a identificat nici o asociere între temperatura corporală şi IPC.

Cuvinte cheie: Infecția plăgii chirurgicale, oxigen suplimentar, laparotomie, terapie lichidiană intraoperatorie, temperatură corporală perioperaorie, studiu clinic PROXI

\begin{abstract}
Background: Use of supplemental oxygen during surgery to reduce the incidence of SSI was investigated in the PROXI trial, which found no reduced frequency of SSI. Subsequently, it has been suggested that a restrictive fluid regimen and hypothermia in some patients could explain why no beneficial effect of supplemental oxygen was found. We evaluated the association between the occurrence of SSI and two perioperative factors, volume of infused fluid and body temperature (BT). Methods: We used data from the PROXI trial including 1,386 patients undergoing laparotomy randomly assigned to receive $80 \%$ or $30 \%$ oxygen during surgery. A fluid infusion index (FII) was calculated for each patient as the volume of infused fluids/body weight/duration of surgery.

Results: SSI occurred in $18.9 \%$ of the patients in the lower FII tertile group (OR=0.86; $\mathrm{P}=0.41$ ), in $20.4 \%$ in the upper FII tertile group ( $\mathrm{OR}=1.49 ; \mathrm{P}=0.05)$, in $19.7 \%$ of the patients with hypothermia $(\mathrm{OR}=1.28 ; \mathrm{P}=0.25)$ and in $25.0 \%$ with hyperthermia $(\mathrm{OR}=1.26 ; \mathrm{P}=0.52)$. An increased risk of SSI $(\mathrm{OR}=3.15 ; \mathrm{P}=0.01)$ was found in patients having both hypothermia and emergency surgery.

Conclusion: A trend towards an increased risk of SSI was seen in patients who received a greater volume of intravenous fluid. No association was found between BT and SSI.
\end{abstract}

Key words: Surgical site infection, supplemental oxygen, laparotomy, intraoperative fluid therapy, perioperative body temperature, the PROXI trial

\section{Introduction}

Surgical site infection (SSI) is a common complication following surgical procedures, leading to antibiotic therapy, reoperations, prolonged hospitalization, higher mortality, and increased hospital costs (1-3).

The most important defence against surgical pathogens is mediated by neutrophils' oxidative killing. This process depends on the partial pressure of oxygen in the wound, which may be improved by increasing the concentration of inspired oxygen (4-6). Accordingly, the frequency of SSI might be reduced by supplemental oxygen during surgery. This concept has been tested in many randomized trials (7). One of the largest of these trials, the Danish PROXI trial, included 1,386 patients undergoing elective or emergency laparotomy. Patients were randomized to receive $80 \%$ or $30 \%$ oxygen during surgery and for the first two hours after surgery. The study found no statistically significant differences in the incidence of SSI between the groups (8).

An increase in oxygen tension in a wound secondary to a higher inspiratory oxygen fraction requires adequate perfusion. A randomized trial by Greif et al in 2000 found that use of high inspired oxygen fraction (80\% vs. 30\%) during and after colorectal surgery significantly reduced the risk of SSI (9). In order to maintain a sufficient perfusion to the wound all patients were aggressively hydrated intraoperatively with intravenous fluid administration equivalent to $15 \mathrm{~mL} / \mathrm{kg} / \mathrm{hr}$ ("liberal" fluid therapy). Hunt et al addressed that fluid 
volumen administered in the PROXI trial were smaller ("restrictive" fluid therapy) (10). Normothermia is also important in maintaining peripheral perfusion (10). It was thus hypothesized that some patients in the PROXI trial had lower oxygen tension in the surgical wound, there by impeding the oxidative bacterial killing by neutrophils. Accordingly, the intravenous fluid regimen and the fact that it was not possible to maintain normothermia in all patients during surgery, might explain why the frequency of SSI was not reduced in the group of patients assigned to $80 \%$ compared with $30 \%$ oxygen in the PROXI trial.

The fluid regimen in the PROXI trial was chosen to ensure normovolaemia and specifically corresponded to the restrictive allocation arm in a randomized study, which concluded that such a regimen reduced the incidence of SSI (11). Nevertheless, it can be claimed that a high perioperative inspiratory oxygen fraction is only shown to prevent SSI under conditions with high tissue perfusion maintained using a "liberal" fluid regimen.

The aim of this study was to evaluate the possible association between the occurrence of SSI and two perioperative factors, namely volume of infused fluid and body temperature (BT) among the patients included in the PROXI trial. We hypothesized that a reduced frequency of SSI could be detected in patients who received a high volume of infused fluid and were normothermic during surgery.

\section{Material and Method}

We used data from the PROXI trial, which included patients aged 18 years and over admitted for an elective or emergency laparotomy (8). Only patients with suspected malignancy were included in cases where laparotomy was performed due to gynaecological disease (12). Patients were excluded in the following cases: general anaesthesia within 30 days, chemotherapy for malignancy within 3 months, inability to provide informed consent, and preoperative arterial haemoglobin oxygen saturation below $90 \%$ without supplemental oxygen assessed by pulse oximetry (8).
A restrictive fluid regimen was used, aiming at normovolaemia and a postoperative body weight increase less than $1 \mathrm{~kg}$. No intravenous fluids were given preoperatively unless the patient had fluid deficit due to acute illness. During surgery, intravenous fluids were administered only to replace measured or calculated deficits in order to maintain a urinary output above $1 \mathrm{~mL} / \mathrm{kg} / \mathrm{hr}$. A blood loss greater than $500 \mathrm{~mL}$ was replaced 1:1 with colloid and, if blood loss exceeded $20 \mathrm{~mL} / \mathrm{kg}$, blood transfusion was initiated (13).

During surgery, forced air warming and warmed fluids were used to avoid hypothermia. The patients' BT (core) was measured continuously, most often in the nasopharynx, and it was aimed to maintain values between 36 and $37^{\circ} \mathrm{C}$. BT was recorded at the end of the surgical procedure (13).

The patients included in the PROXI trial underwent different types of surgery with varying amounts of blood loss and, as a result, the intravenous fluid therapy given perioperatively varied considerably (8). To compare the administration of fluids among the patients, a individual fluid infusion index (FII) was calculated as the volume of infused fluid/body weight/duration of surgery. The volume of infused fluid was calculated by adding the volume of blood products, the volume of infused colloids and one third of infused crystalloids minus the volume of blood loss, assuming that $2 / 3$ of the infused crystalloids leave the intravascular compartment.

Development of postoperative SSI was assessed daily by a surgical investigator blinded to allocation. After discharge, a follow-up visit was undertaken (8).

\section{Statistical Analysis}

The association between the volume of infused fluid and BT and the occurrence of SSI was assessed by logistic regression with adjustment for known predictive factors for SSI (daily smoking, obesity, duration of surgery, wound contamination) as well as allocation, emergency surgery, diabetes, and study centre.

The statistical analyses were performed 
with the covariates FII and BT as both continuous and categorical variables. In the latter case, FII was classified in tertiles $(\mathrm{FII}<$ $2.71 \mathrm{~mL} / \mathrm{kg} / \mathrm{hr} ;$ FII $2.71-5.64 \mathrm{~mL} / \mathrm{kg} / \mathrm{hr} ;$ FII $>$ $5.64 \mathrm{~mL} / \mathrm{kg} / \mathrm{hr}$ ) and BT was categorised as hypothermia $\left(\mathrm{BT} \leq 35.4^{\circ} \mathrm{C}\right)$, normothermia $(\mathrm{BT}$ $\left.35.5^{\circ} \mathrm{C}-37.5^{\circ} \mathrm{C}\right)$ and hyperthermia $(\mathrm{BT} \geq$ $37.6^{\circ} \mathrm{C}$ ). The middle tertile of FII and normothermia were used as reference groups. Additionally, univariable analyses were performed with data stratified according to the type of surgery (elective and emergency).

$\mathrm{P}<0.05$ was considered statistically significant. Statistical software was SPSS version 20.0 .

\section{Results}

Data regarding perioperative fluid administration were missing in 4 patients, impeding the calculation of FII in these cases. Additionally, BT was not recorded in 114 patients. Thus 1,382

Table 1. Patient characteristics and perioperative data

\begin{tabular}{|c|c|c|c|c|c|c|}
\hline & \multicolumn{3}{|c|}{ Fluid infusion index } & \multicolumn{3}{|c|}{ Body temperature $^{A}$} \\
\hline & $\begin{array}{r}<2.71 \mathrm{~mL} / \mathrm{kg} / \mathrm{h} \\
(\mathrm{n}=461)\end{array}$ & $\begin{array}{r}2.71-5.64 \mathrm{~mL} / \mathrm{kg} / \mathrm{h} \\
(\mathrm{n}=460)\end{array}$ & $\begin{array}{r}>5.64 \mathrm{~mL} / \mathrm{kg} / \mathrm{h} \\
(\mathrm{n}=461)\end{array}$ & $\begin{array}{l}\leq 35.4^{\circ} \mathrm{C} \\
(\mathrm{n}=203)\end{array}$ & $\begin{array}{r}35.5-37.5^{\circ} \mathrm{C} \\
(\mathrm{n}=1013)\end{array}$ & $\begin{array}{r}\geq 37.6^{\circ} \mathrm{C} \\
(\mathrm{n}=56)\end{array}$ \\
\hline Age, median (5\%-95\%), yrs & $62(29-82)$ & $63(31-84)$ & $67(31-87)$ & $66(42-86)$ & $64(30-85)$ & $52(21-78)$ \\
\hline Males, $n(\%)$ & $218(47.3)$ & $205(44.6)$ & $154(33.4)$ & $56(27.6)$ & $429(42.3)$ & $36(64.3)$ \\
\hline Body mass index, median $(5 \%-95 \%)^{\mathrm{B}}$ & $26(20-39)$ & $25(19-35)$ & $23(17-32)$ & $24(18-31)$ & $25(18-36)$ & $25(18-38)$ \\
\hline $\begin{array}{l}\text { ASA physical status score, } \mathrm{n}(\%) \\
1 \\
2 \\
3 \\
4\end{array}$ & $\begin{array}{r}139(30.2) \\
239(51.8) \\
82(17.8) \\
1(0.2)\end{array}$ & $\begin{array}{r}129(28.0) \\
260(56.5) \\
70(15.2) \\
1(0.2)\end{array}$ & $\begin{array}{r}105(22.8) \\
249(54.0) \\
100(21.7) \\
7(1.5)\end{array}$ & $\begin{array}{r}54(26.6) \\
116(57.1) \\
32(15.8) \\
1(0.5)\end{array}$ & $\begin{array}{r}274(27.0) \\
544(53.7) \\
190(18.8) \\
5(0.5)\end{array}$ & $\begin{array}{r}19(33.9) \\
30(53.6) \\
7(12.5) \\
0(0.0)\end{array}$ \\
\hline Emergency surgery, $n(\%)$ & $95(20.6)$ & $106(23.0)$ & $181(39.3)$ & $23(11.3)$ & $283(27.9)$ & $44(78.6)$ \\
\hline Daily smoker, $\mathrm{n}(\%)$ & $137(30.0)$ & $128(27.8)$ & $150(32.5)$ & $49(24.1)$ & $311(30.7)$ & $17(30.4)$ \\
\hline Diabetes mellitus, $\mathrm{n}(\%)$ & $38(8.2)$ & $34(7.4)$ & $32(6.9)$ & $10(4.9)$ & $85(8.4)$ & $1(1.8)$ \\
\hline $\begin{array}{l}\text { SENIC }^{\mathrm{c}}, \mathrm{n}(\%) \\
\quad 1 \\
2 \\
3 \\
4\end{array}$ & $\begin{array}{r}120(26.0) \\
253(54.9) \\
77(16.7) \\
11(2.4)\end{array}$ & $\begin{array}{r}115(25.0) \\
264(57.4) \\
73(15.9) \\
8(1.7)\end{array}$ & $\begin{array}{r}218(47.3) \\
186(40.3) \\
49(10.6) \\
8(1.7)\end{array}$ & $\begin{array}{r}59(29.1) \\
109(53.7) \\
31(15.3) \\
4(2.0)\end{array}$ & $\begin{array}{r}342(33.7) \\
508(50.1) \\
149(14.7) \\
14(1.4)\end{array}$ & $\begin{array}{r}25(44.6) \\
25(44.6) \\
4(7.1) \\
2(3.6)\end{array}$ \\
\hline $\begin{array}{l}\text { NNISS }^{\mathrm{D}}, \mathrm{n}(\%) \\
0 \\
1 \\
2 \\
3\end{array}$ & $\begin{array}{r}154(33.4) \\
223(48.4) \\
70(15.2) \\
14(3.0)\end{array}$ & $\begin{array}{r}199(43.3) \\
172(37.4) \\
84(18.3) \\
5(1.1)\end{array}$ & $\begin{array}{r}246(53.4) \\
168(36.4) \\
43(9.3) \\
4(0.9)\end{array}$ & $\begin{array}{r}88(43.3) \\
87(42.9) \\
27(13.3) \\
1(0.5)\end{array}$ & $\begin{array}{r}451(44.5) \\
403(39.8) \\
143(14.1) \\
16(1.6)\end{array}$ & $\begin{array}{r}21(37.5) \\
22(39.3) \\
11(19.6) \\
2(3.6)\end{array}$ \\
\hline $80 \%$ oxygen, $n(\%)$ & $230(49.9)$ & $227(49.3)$ & $226(49.0)$ & $102(50.2)$ & $503(49.7)$ & $32(57.1)$ \\
\hline $\begin{array}{l}\text { Surgical procedure, } n(\%) \\
\text { Colorectal } \\
\text { Gynaecological } \\
\text { Small-bowel } \\
\text { Appendectomy } \\
\text { Other }{ }^{\mathrm{E}}\end{array}$ & $\begin{array}{r}205(44.5) \\
104(22.6) \\
41(8.9) \\
43(9.3) \\
68(14.8)\end{array}$ & $\begin{array}{r}225(48.9) \\
89(19.3) \\
47(10.2) \\
46(10.0) \\
53(11.5)\end{array}$ & $\begin{array}{r}202(43.8) \\
74(16.1) \\
69(15.0) \\
35(7.6) \\
81(17.6)\end{array}$ & $\begin{array}{r}110(54.2) \\
59(29.1) \\
15(7.4) \\
1(0.5) \\
18(8.9)\end{array}$ & $\begin{array}{r}448(44.2) \\
206(20.3) \\
125(12.3) \\
93(9.2) \\
141(13.9)\end{array}$ & $\begin{array}{r}11(19.6) \\
0(0.0) \\
7(12.5) \\
24(42.9) \\
14(25.0)\end{array}$ \\
\hline $\begin{array}{l}\text { Diagnosis, } \mathrm{n}(\%) \\
\text { Cancer } \\
\text { Benign neoplasm } \\
\text { Appendicitis } \\
\text { Intestinal obstruction due to benign disease } \\
\text { Inflammatory bowel disease } \\
\text { Diverticulitis } \\
\text { Other }\end{array}$ & $\begin{array}{r}253(54.9) \\
33(7.2) \\
39(8.5) \\
24(5.2) \\
20(4.3) \\
27(5.9) \\
65(14.1)\end{array}$ & $\begin{array}{r}247(53.7) \\
38(8.3) \\
48(10.4) \\
26(5.6) \\
30(6.5) \\
16(3.5) \\
55(12.0)\end{array}$ & $\begin{array}{r}211(45.8) \\
37(8.0) \\
34(7.4) \\
74(16.1) \\
29(6.3) \\
14(3.0) \\
62(13.4)\end{array}$ & $\begin{array}{r}134(66.0) \\
17(8.4) \\
2(1.0) \\
8(3.9) \\
8(3.9) \\
9(4.4) \\
25(12.3)\end{array}$ & $\begin{array}{r}511(50.4) \\
83(8.2) \\
87(8.6) \\
100(9.9) \\
67(6.6) \\
38(3.8) \\
127(12.5)\end{array}$ & $\begin{array}{r}8(14.3) \\
3(5.4) \\
25(44.6) \\
7(12.5) \\
2(3.6) \\
2(3.6) \\
9(16.1)\end{array}$ \\
\hline Duration of surgery, median (5\%-95\%), min & $\begin{array}{r}158 \\
(48-350)\end{array}$ & $\begin{array}{r}145 \\
(40-291)\end{array}$ & $\begin{array}{r}97 \\
(30-225)\end{array}$ & $\begin{array}{r}140 \\
(55-301)\end{array}$ & $\begin{array}{r}130 \\
(35-295)\end{array}$ & $\begin{array}{r}89 \\
(33-397)\end{array}$ \\
\hline $\begin{array}{l}\text { Operation classification, } \mathrm{n}(\%) \\
\text { Clean } \\
\text { Clean-contaminated } \\
\text { Contaminated } \\
\text { Dirty-infected }\end{array}$ & $\begin{array}{r}114(24.7) \\
261(56.6) \\
74(16.1) \\
12(2.6)\end{array}$ & $\begin{array}{r}97(21.1) \\
268(58.3) \\
88(19.1) \\
7(1.5)\end{array}$ & $\begin{array}{r}107(23.2) \\
265(57.5) \\
71(15.4) \\
18(3.9)\end{array}$ & $\begin{array}{r}48(23.6) \\
117(57.6) \\
37(18.2) \\
1(0.5)\end{array}$ & $\begin{array}{r}252(24.9) \\
583(57.6) \\
151(14.9) \\
27(2.7)\end{array}$ & $\begin{array}{r}8(14.3) \\
24(42.9) \\
19(33.9) \\
5(8.9)\end{array}$ \\
\hline Surgical site infection, $\mathrm{n}(\%)$ & $87(18.9)$ & $91(19.8)$ & $94(20.4)$ & $40(19.7)$ & $192(19.0)$ & $14(25.0)$ \\
\hline
\end{tabular}

Legends: ASA: American Society of Anesthesiologists; SENIC: Study of the Efficacy of Nosocomial Infection Control; NNISS: National Nosocomial Infection Surveillance System. ${ }^{\text {A }}$ - Body temperature measured at the end of surgery. ${ }^{B}$ - Calculated as weight in kilograms divided by squared height in meters. ${ }^{C}-$ In the SENIC scoring system, 1 point is given for each of (1) presence of three or more diagnoses; (2) surgery lasting longer than 2 hours; (3) operation classified as contaminated or dirty-infected; (4) abdominal surgery.[27] ${ }^{\mathrm{D}}$ - In the NNISS scoring system, 1 point is given for (1) ASA score of 3, 4 or 5; (2) operation classified as contaminated or dirty-infected; (3) operation lasting longer than expected for the operative procedure being performed.[28] ${ }^{\mathrm{E}}$ Includes cholecystectomy, repair of hernia, gastric and hepatobiliary resections, nephrectomy and splenectomy. ${ }^{\mathrm{F}}$ - Includes perforated peptic ulcer and cholecytolithiasis. 
and 1,272 patients were available for analysis of the association between FII or BT and SSI, respectively. SSI occurred in 272 of 1,382 (19.7\%) patients (Table 1).

Some characteristics had a skewed distribution according to FFI and BT. Larger amounts of infused fluid per body weight were associated with high age, female gender, low body mass index, high ASA physical score, emergency surgery, low SENIC-score (27), low NNISS-score (28), small-bowel procedure, intestinal obstruction due to benign disease, and short duration of surgery.

Hyperthermia was more common in young male patients with a high body mass index, in emergency surgery, and in patients with dirtyinfected surgical wounds. Patients undergoing prolonged surgical procedures were more prone to hypothermia.

\section{Univariable Analyses}

No significant association was found between FII and the incidence of SSI (Table 2). There was a significantly increased risk of SSI $(\mathrm{OR}=3.15 ; \mathrm{P}=0.01)$ in patients having both emergency surgery and hypothermia (Table 2). A significant interaction $(\mathrm{P}=0.01)$ was found between the variables hypothermia and emergency surgery, indicating that the effect of hypothermia depended on whether the patient underwent surgery in an elective or emergency situation.

\section{Multivariable Analyses}

There was no significant association between SSI and FII when FII was included as a continuous variable $(\mathrm{OR}=1.03 ; \mathrm{P}=0.09 ; \mathrm{OR}$ given as a function of $1 \mathrm{~mL} / \mathrm{kg} / \mathrm{h}$ increase of FII). SSI occurred in $18.9 \%$ of the patients in the lower tertile FII group $(\mathrm{OR}=0.86 ; \mathrm{P}=0.41)$ and in $20.4 \%$ in the upper tertile FII group $(\mathrm{OR}=1.49 ; \mathrm{P}=0.05)$ compared with $19.8 \%$ in the reference group (Table 3). No statistically significant interaction $(\mathrm{P}=0.23)$ was found between the allocation and FFI.

There was no significant association between SSI and BT when BT was included as a continuous variable $(\mathrm{OR}=0.89 ; \mathrm{P}=0.28, \mathrm{OR}$ given as a function of $0.1^{\circ} \mathrm{C}$ increase of $\mathrm{BT}$ ) or a categorical variable. SSI occurred in 19.7\% of the patients with hypothermia $(\mathrm{OR}=1.28$; $\mathrm{P}=0.25)$ and in $25.0 \%$ with hyperthermia $(\mathrm{OR}=1.26 ; \mathrm{P}=0.52)$ compared with $19.0 \%$ in the reference group (Table 3).

Table 2. Intraoperative fluid therapy and body temperature as risk factors for surgical site infection. Univariable analyses

\begin{tabular}{|c|c|c|c|c|c|}
\hline Variable & Type of surgery & $\mathrm{n}$ & SSI (\%) & $\begin{array}{r}\text { Univariable OR } \\
(95 \% \mathrm{CI})\end{array}$ & $\mathbf{P}$ \\
\hline Fluid Infusion Index, continuous variable & $\begin{array}{r}\text { Elective } \\
\text { Emergency }\end{array}$ & $\begin{array}{r}1000 \\
382\end{array}$ & $\begin{array}{r}196(19.6) \\
76(19.9)\end{array}$ & $\begin{array}{l}0.99(0.95-1.02) \\
1.00(0.97-1.04)\end{array}$ & $\begin{array}{l}0.48 \\
0.96\end{array}$ \\
\hline \multicolumn{6}{|c|}{ Fluid Infusion Index, categorical variable, $(\mathrm{mL} / \mathrm{kg} / \mathrm{h})$} \\
\hline$<2.71$ & Elective & 366 & $69(18.9)$ & $0.89(0.62-1.29)$ & 0.55 \\
\hline $2.71-5.64$ & Elective & 354 & $73(20.6)$ & 1 & \\
\hline$>5.64$ & Elective & 280 & $54(19.3)$ & $0.92(0.62-1.36)$ & 0.68 \\
\hline$<2.71$ & Emergency & 95 & $18(18.9)$ & $1.14(0.56-2.35)$ & 0.72 \\
\hline $2.71-5.64$ & Emergency & 106 & $18(17.0)$ & 1 & \\
\hline$>5.64$ & Emergency & 181 & $40(22.1)$ & $1.39(0.75-2.57)$ & 0.30 \\
\hline \multirow[t]{2}{*}{ Body temperature, continuous variable } & Elective & 922 & $179(19.4)$ & $1.18(0.92-1.52)$ & 0.20 \\
\hline & Emergency & 350 & $67(19.1)$ & $0.87(0.63-1.20)$ & 0.38 \\
\hline \multicolumn{6}{|l|}{ Body temperature, categorical variable, $\left({ }^{\circ} \mathrm{C}\right)$} \\
\hline$\leq 35.4$ & Elective & 180 & $31(17.2)$ & $0.85(0.55-1.30)$ & 0.45 \\
\hline $35.5-37.5$ & Elective & 730 & $144(19.7)$ & 1 & \\
\hline$\geq 37.6$ & Elective & 12 & $4(33.3)$ & $2.04(0.60-6.85)$ & 0.25 \\
\hline$\leq 35.4$ & Emergency & 23 & $9(39.1)$ & $3.15(1.29-7.69)$ & 0.01 \\
\hline $35.5-37.5$ & Emergency & 283 & $48(17.0)$ & 1 & \\
\hline$\geq 37.6$ & Emergency & 44 & $10(22.7)$ & $1.44(0.67-3.11)$ & 0.35 \\
\hline
\end{tabular}


Table 3. Intraoperative fluid therapy and body temperature as risk factors for surgical site infection. Multivariable analyses

\begin{tabular}{|c|c|c|c|c|}
\hline Variable & $n$ & SSI (\%) & $\begin{array}{r}\text { Adjusted OR } \\
(95 \% \mathrm{Cl})^{\mathrm{A}}\end{array}$ & $P$ \\
\hline Fluid Infusion Index, continuous variable & 1382 & $272(19.7)$ & $1.03(1.00-1.06)$ & 0.09 \\
\hline \multicolumn{5}{|c|}{ Fluid Infusion Index, categorical variable, mL/kg/h } \\
\hline$<2.71$ & 461 & $87(18.9)$ & $0.86(0.60-1.23)$ & 0.41 \\
\hline $2.71-5.64$ & 460 & $91(19.8)$ & 1 & \\
\hline$>5.64$ & 461 & $94(20.4)$ & $1.49(1.00-2.05)$ & 0.05 \\
\hline Body temperature, continuous variable & 1272 & $246(19.3)$ & $0.89(0.71-1.10)$ & 0.28 \\
\hline \multicolumn{5}{|l|}{ Body temperature, categorical variable, ${ }^{\circ} \mathrm{C}$} \\
\hline$\leq 35.4$ & 203 & $40(19.7)$ & $1.28(0.84-1.93)$ & 0.25 \\
\hline $35.5-37.5$ & 1013 & $192(19.0)$ & 1 & \\
\hline$\geq 37.6$ & 56 & $14(25.0)$ & $1.26(0.63-2.50)$ & 0.52 \\
\hline
\end{tabular}

\section{Discussion}

The main finding was a trend towards an increased risk of SSI in patients who received a greater volume of intravenous fluid. No association was found between $\mathrm{BT}$ at the end of surgery and SSI. Thus, the study does not support the hypothesis that a restrictive intravenous fluid regimen and hypothermia could explain the absence of a reduction of SSI in patients assigned to $80 \%$ in the PROXI trial. An increased incidence of SSI was, however, found among the minority of hypothermic patients who underwent emergency surgery.

The effect of different fluid regimens on the incidence of complications, including SSI, after abdominal surgery has been assessed in several randomized trials $(11,14-18)$. A restrictive fluid volume regimen was associated with a significantly lower risk of postoperative complications in three trials $(11,16,18)$. Although these trials did not assess the incidence of SSI in specific analyses, they all reported a lower incidence of SSI among patients randomized to the restricted fluid volume regimen. On the other hand, no difference in the incidence of SSI was found in three other trials $(14,15,17)$. The total amount of intravenous fluid that was administered during and after surgery to patients assigned to the restricted fluid regimen varied considerably among the trials as did the definitions of the terms "intraoperative" and "postoperative" making impossible a proper comparison of the fluid administration (11, 14-18). As opposed to the PROXI trial, the other trials included a smaller number and selected patients reducing the external validity of their findings.

It is widely agreed that perioperative warming reduces the incidence of SSI (19-21). Patients in the PROXI trial were all managed to avoid hypothermia aiming at a BT of 36 to $37^{\circ} \mathrm{C}(13,22)$. Despite these efforts, 203 patients $(16 \%)$ had a BT of $\leq 35.4^{\circ} \mathrm{C}$ at the end of surgery (mean $35.1^{\circ} \mathrm{C}$ ). Although the mean BT of the patients with hypothermia in the PROXI trial corresponded to the temperatures recorded in trials that found an increased incidence of SSI among these patients, we were not able to detect the same association $(19,20)$. One explanation could be the lack of randomization to different temperature preserving regimens in our study as well as the possible occurrence of competing (unknown) risk factors for SSI in patients with normal or high BT. Hyperthermic patients had, for example, a much higher frequency of contaminated and dirty-infected procedures.

Comparing the present findings with the first trial favouring $80 \%$ oxygen, the overall median BT at the end of surgery was almost identical in the two groups of patients randomized to $80 \%$ oxygen $\left(36.1^{\circ} \mathrm{C}\right.$ vs. $\left.35.9^{\circ} \mathrm{C}\right)$ (8, 9). Thus, local vasoconstriction due to hypothermia is an unlikely explanation as to why the PROXI trial did not report an effect of 
$80 \%$ oxygen on the incidence of SSI, as formerly suggested (10).

Hypothermia was associated with a significantly increased risk of SSI specifically in patients subjected to emergency surgery. The association between hypothermia during emergency surgery and SSI has been investigated in 524 trauma patients. Patients with SSI had a significantly lower mean intraoperative BT. Consistent with the present study, an intraoperative $\mathrm{BT}$ of $35^{\circ} \mathrm{C}$ was the most important predictor for SSI development (23). Hypothermia activates the sympathetic nervous system leading to peripheral vasoconstriction, reduced supply of oxygen to the wound, low partial pressure of oxygen and inhibition of the crucial oxidative bactericide effect of neutrophils (4-6, 24). Moreover, hypothermia impairs innate immune functions (25). Patients undergoing emergency abdominal surgery may have sepsis and hypovolaemia. In addition, cardiovascular or respiratory dysfunction is more prevalent in these patients. Pain may also lead to peripheral vasoconstriction (26). Accordingly, patients undergoing emergency surgery should be considered particularly sensitive to hypothermia.

The strength of this study is the large number of patients included in the analyses, allowing multivariable analyses of several risk factors and the completeness of the 14-day follow-up with regard to the rate of SSI as the primary outcome. We believe that the FFI provided a useful measure of the fluid therapy in individual patients, taking body weight and duration of surgery into consideration. The PROXI trial included a variety of patients undergoing elective or emergency laparotomy due to gastrointestinal or gynaecological disease at various centres, suggesting substantial external validity of the results.

The present study has some limitations. The volume of fluid administration and actual BT depended on compliance with the protocol rather than random allocation. Accordingly, confounding by indication must be considered in the interpretation of the results, e.g. a larger amount of fluid may have been given to patients who were sicker. No objective meas- ures of volume status, such as central venous pressure, blood lactate levels, or central venous oxygen saturation were recorded intraoperatively, although they may have been used to guide fluid therapy. Furthermore, the calculated FFI must be considered as an estimate of the volume of fluid given to each patient. BT at the end of surgery was not recorded in all cases and the mean temperature during surgery was not registered.

\section{Conclusions}

In conclusions the main finding was a trend towards an increased risk of SSI in patients who received a greater volume of intravenous fluid. Accordingly no association was found between BT at the end of surgery and SSI. Thus, a restrictive intravenous fluid regimen and hypothermia were unlikely explanations of the lack of benefit from allocation to $80 \%$ oxygen, as reported in the PROXI trial. The present study is consistent with findings in other studies demonstrating an increased incidence of SSI among patients with high volume of infused fluid during surgery. A BT $\leq 35.4^{\circ} \mathrm{C}$ after emergency surgery was associated with an increased risk of SSI.

\section{Acknowledgements}

The authors thank Karl Bang Christensen, Department of Biostatistics, University of Copenhagen, for statistical advice and analysis.

\section{Conflicts of Interest}

None declared.

\section{Source of Funding}

The study was supported by the Danish Medical Research Council (271-05-0206), the Lundbeck Foundation (402/06), Rigshospitalet's Research Council, the Novo Nordisk Foundation, the Aase and Ejnar Danielsens Foundation (105728), the A.P. Møller Foundation for the Advancement of Medical Science, the Danish Society of Anaesthesiology and Intensive Care Medicine's 
Research Initiative, the Beckett-Foundation, the Brødrene Hartmanns Foundation, the Etly and Jørgen Stjerngrens Foundation, the Tryg Foundation and Ambu. Trial registration: clinicaltrials.gov, identifier NCT00364741.

\section{References}

1. Weber WP, Zwahlen M, Reck S, Feder-Mengus C, Misteli H, Rosenthal $R$, et al. Economic burden of surgical site infections at a European university hospital. Infect Control Hosp Epidemiol. 2008; 29(7):623-9.

2. de Lissovoy G, Fraeman K, Hutchins V, Murphy D, Song D, Vaughn BB. Surgical site infection: incidence and impact on hospital utilization and treatment costs. Am J Infect Control. 2009;37(5): 387-397.

3. Astagneau P, Rioux C, Golliot F, Brücker G, INCISO Network Study Group. Morbidity and mortality associated with surgical site infections: results from the 1997-1999 INCISO surveillance. J Hosp Infect. 2001; 48(4):267-74

4. Allen DB, Maguire JJ, Mahdavian M, Wicke C, Marcocci L, Scheuenstuhl $\mathrm{H}$, et al. Wound hypoxia and acidosis limit neutrophil bacterial killing mechanisms. Arch Surg. 1997;132(9):991-6.

5. Hopf HW, Hunt TK, West JM, Blomquist P, Goodson WH 3rd, Jensen $\mathrm{JA}$, et al. Wound tissue oxygen tension predicts the risk of wound infection in surgical patients. Arch Surg. 1997;132(9):997-1004; discussion 1005.

6. Hopf HW, Holm J. Hyperoxia and infection. Best Pract Res Clin Anaesthesiol. 2008;22(3):553-69.

7. Wetterslev J, Meyhoff CS, Jørgensen LN, Gluud C, Lindschou J, Rasmussen LS. The effects of high perioperative inspiratory oxygen fraction for adult surgical patients. Cochrane Database Syst Rev. 2015;(6):CD008884.

8. Meyhoff CS, Wetterslev J, Jorgensen LN, Henneberg SW, Høgdall C, Lundvall $\mathrm{L}$, et al. Effect of high perioperative oxygen fraction on surgical site infection and pulmonary complications after abdominal surgery: the PROXI randomized clinical trial. JAMA. 2009; 302(14):1543-50. doi: 10.1001/jama.2009.1452.

9. Greif R, Akça O, Horn EP, Kurz A, Sessler DI; Outcomes Research Group. Supplemental perioperative oxygen to reduce the incidence of surgical-wound infection. N Engl J Med. 2000;342(3):161-7.

10. Hunt TK, Hopf HW. High inspired oxygen fraction and surgical site infection. JAMA. 2009;302(14):1588-9.

11. Brandstrup B, Tonnesen H, Beier-Holgersen R, Hjortsø E, Ørding H, Lindorff-Larsen $\mathrm{K}$, et al. Effects of intravenous fluid restriction on postoperative complications: comparison of two perioperative fluid regimens: a randomized assessor-blinded multicenter trial. Ann Surg. 2003;238(5):641-8.

12. Jacobs I, Oram D, Fairbanks J, Turner J, Frost C, Grudzinskas JG. A risk of malignancy index incorporating CA 125, ultrasound and menopausal status for the accurate preoperative diagnosis of ovarian cancer. Br J Obstet Gynaecol. 1990;97(10):922-9.

13. Meyhoff CS, Wetterslev J, Jorgensen LN, Henneberg SW, Simonsen I, Pulawska T, et al. Perioperative oxygen fraction - effect on surgical site infection and pulmonary complications after abdominal surgery: a randomized clinical trial. Rationale and design of the PROXI-Trial. Trials. 2008;9:58.

14. Kabon B, Akca O, Taguchi A, Nagele A, Jebadurai R, Arkilic CF, et al. Supplemental intravenous crystalloid administration does not reduce the risk of surgical wound infection. Anesth Analg. 2005; 101(5):1546-53.

15. Abraham-Nordling M, Hiern F, Pollack J, Prytz M, Borg T, Kressner U. Randomized clinical trial of fluid restriction in colorectal surgery. $\mathrm{Br} \mathrm{J}$ Surg. 2012;99(2):186-91.

16. Gao T, Li N, Zhang JJ, Xi FC, Chen QY, Zu WM, et al. Restricted intravenous fluid regimen reduces the rate of postoperative complications and alters immunological activity of elderly patients operated for abdominal cancer: a randomized prospective clinical trail. World J Surg. 2012;36(5):993-1002.

17. Holte K, Foss NB, Andersen J, Valentiner L, Lund C, Bie P, et al. Liberal or restrictive fluid administration in fast-track colonic surgery: a randomized, double-blind study. $\mathrm{Br} \mathrm{J}$ Anaesth. 2007; 99(4):500-8. Epub 2007 Aug 6.

18. Nisanevich V, Felsenstein I, Almogy G, Weissman C, Einav S, Matot I. Effect of intraoperative fluid management on outcome after intraabdominal surgery. Anesthesiology. 2005;103(1):25-32.

19. Kurz A, Sessler DI, Lenhardt R. Perioperative normothermia to reduce the incidence of surgical-wound infection and shorten hospitalization. Study of Wound Infection and Temperature Group. N Engl J Med. 1996;334(19):1209-15.

20. Wong PF, Kumar S, Bohra A, Whetter D, Leaper DJ. Randomized clinical trial of perioperative systemic warming in major elective abdominal surgery. Br J Surg. 2007;94(4):421-6.

21. Sajid MS, Shakir AJ, Khatri K, Baig MK. The role of perioperative warming in surgery: a systematic review. Sao Paulo Med J. 2009; 127(4):231-7.

22. Fearon KC, Ljungqvist 0 , Von Meyenfeldt $M$, Revhaug $A$, Dejong $\mathrm{CH}$, Lassen $\mathrm{K}$, et al. Enhanced recovery after surgery: a consensus review of clinical care for patients undergoing colonic resection. Clin Nutr. 2005;24(3):466-77. Epub 2005 Apr 21.

23. Seamon MJ, Wobb J, Gaughan JP, Kulp H, Kamel I, Dempsey DT. The effects of intraoperative hypothermia on surgical site infection: an analysis of 524 trauma laparotomies. Ann Surg. 2012;255(4):789-95.

24. Frank SM, Higgins MS, Breslow MJ, Fleisher LA, Gorman RB, Sitzmann JV, et al. The catecholamine, cortisol, and hemodynamic responses to mild perioperative hypothermia. A randomized clinical trial. Anesthesiology. 1995;82(1):83-93.

25. Qadan M, Gardner SA, Vitale DS, Lominadze D, Joshua IG, Polk HC Jr. Hypothermia and surgery: immunologic mechanisms for current practice. Ann Surg. 2009;250(1):134-40.

26. Chapman CR, Tuckett RP, Song CW. Pain and stress in a systems perspective: reciprocal neural, endocrine, and immune interactions. J Pain. 2008;9(2):122-45. Epub 2007 Dec 21.

27. Haley RW, Culver DH, Morgan WM, White JW, Emori TG, Hooton TM. Identifying patients at high risk of surgical wound infection. A simple multivariate index of patient susceptibility and wound contamination. Am J Epidemiol. 1985;121(2):206-15.

28. Culver DH, Horan TC, Gaynes RP, Martone WJ, Jarvis WR, Emori TG, et al. Surgical wound infection rates by wound class, operative procedure, and patient risk index. National Nosocomial Infections Surveillance System. Am J Med. 1991;91(3B):152S-157S. 